\title{
Empirical Research on the Relationship between Industry Income Gap and Financial Development
}

\author{
Kangyin Lu* \\ School of Business, Northeast Normal University \\ Changchun, P.R.China, 130117 \\ luky440@ nenu.edu.cn
}

\author{
Manxue Chen \\ School of Business, Northeast Normal University \\ Changchun, P.R.China, 130117 \\ chenmx839@nenu.edu.cn
}

\author{
Fenghua Zou \\ Jilin Police College \\ Changchun, P.R.China, 130117
}

\begin{abstract}
On the basis of logical analysis, the macroscopic statistical data are adopted in this paper for the empirical research on the relationship between the industry income gap and the financial development through unit root test, VAR model estimation, Granger causality test and other metrological methods. The research shows that the improvement of the financial development level in China is the cause for the expansion of the industry income gap, and the non-balanced financial development in various industries significantly expands the industry income gap.
\end{abstract}

Keywords-Industry Income Gap; Financial Development; Currency Supply

\section{INTRODUCTION}

Industry, as a mesoeconomic index, has a correlation effect on the macroeconomic, microeconomic and mesoeconomic indexes. Specifically, the industry income gap influences three major macroeconomic indexes ---- economic growth, full employment and price stability, and the macro economy is interacted with the social stability. Meanwhile, various factors reflecting and influencing the industry income gap are too anfractuous and accumulative to form the combined action of the position, function and effect of the industry income gap in the economic system. Viewed from the relationship between the financial development and the industry income gap, the unreasonable expansion of the industry income gap will influence the tendency of the financial market. Meanwhile, the industry development is inseparable from the support of the financial system. In the whole financial development system, the state-owned monopolized industry has strong debt paying ability and low bank loan risk, so the financial system provides preferential policy to the monopolized industry. However, the rapid development of the financial industry will also gradually expand the inter-industry income gap.

\section{DATA SOURCE AND VARIABLE DEFINITION}

Since 2003, the National Bureau of Statistics of China has changed the statistical caliber from the original 16 major industries into 19 major industries. In order to ensure the consistence of the research caliber, only the time-sequence data of China Statistical Yearbook for 2003 2015 are selected as the data for the empirical research.

In this paper, Gini coefficient and Theil index are adopted to measure the industry income gap in order to comprehensively reflect the inter-industry income inequality. As required by the National Bureau of Statistics of China, the currency supply data should include M1 and M2, wherein M2 = $\mathrm{M} 1$ + quasi-currency supply, and currency supply M1 includes circulating currency and current deposit, and the savings deposit is changed as a part of the quasi-currency debt, and the quasi-currency debt includes savings deposit, call deposits, fixed term deposit, other deposits and deposit certificates. Therefore, the dependent variable is selected as the proportion of M2 in the gross domestic product as the financial development index in order to conveniently reflect financial development growth and variation tendency.

TABLE I. VARIABLE DEFINITION

\begin{tabular}{lcc}
\hline Variable Type & Variable Name & Variable Meaning \\
\hline Dependent & Financial & Proportion of currency supply in \\
Variable & Development (JR) & gross domestic product \\
& Gini Coefficient & For investigating the resident \\
Independent & (GINI) & income inequality \\
Variable & Theil Index & For investigating personal or \\
& (THEIL) & regional income inequality \\
\hline
\end{tabular}

\section{QUANTITATIVE ANALYSIS OF INDUSTRY INCOME GAP} AND FINANCIAL DEVELOPMENT

Before VAR vector autoregression model estimation, in order to eliminate the interference of the heteroscedasticity and the price factor on the metrological result, the logarithmic operation is implemented for the dependent variable and the independent variable selected thereby. Firstly, the unit root test is carried out for the industry income gap and the financial development in order to judge whether VAR model estimation is applicable to the industry income gap and the financial development.

Therefore, ADF unit root test [1] is carried out for industry Gini coefficient, Theil index and financial development. As shown in TABLE II, a long-term co-integration relationship 
exists among industry Gini coefficient, Theil index and financial development during $2003 \sim 2015$.

Secondly, on the basis of the qualified unit root test of the dependent variable and the independent variable, VAR model estimation [2] is carried out for the industry income gap and the financial development. According to VAR model estimation, when the lag period is 2, VAR model has optimal lag period and the result of equation (1) and equation (2) can be obtained:

$$
J R=1.1284 * J R(-1)-0.3524 * J R(-2)-3.3504 * G I N I(-1)+8.1343 *
$$$$
\text { GINI(-2)+1.0811 }
$$

$J R=1.1279 * J R(-1)-0.3553 * J R(-2)-8.7428 * T H E I L(-1)+19.720$

$1 *$ THEIL $(-2)+1.3977$

According to VAR vector autoregression model estimation, for the two equations at the lag period of 2, R2 statistical values are both more than 0.9 , and the model has good fitting effect. Meanwhile, the moduli of the reciprocals of the characteristic roots of the two equations are less than 1 , thus indicating that industry Gini coefficient, Theil index and financial development are all located in a unit circle. Therefore, it can be judged that VAR model established in this paper has good stability.

TABLE II. UNIT RoOT TEST OF INDUSTRY INCOME GAP AND FINANCIAL DEVELOPMENT

\begin{tabular}{lcccc}
\hline Variable & $\begin{array}{c}\text { Inspection } \\
\text { Type } \\
(\mathbf{c}, \mathbf{t}, \mathbf{p})\end{array}$ & $\begin{array}{c}\text { ADF Test } \\
\text { Value }\end{array}$ & $\begin{array}{c}\text { Mackinnon } \\
\text { Critical } \\
\text { Value }\end{array}$ & Result \\
\hline LN JR & $(\mathrm{c}, 0,2)$ & -6.6045 & -3.7695 & Unstable \\
$\Delta$ LN J & $(\mathrm{c}, 0,2)$ & $-4.7806^{* * *}$ & -4.4407 & Stable \\
LN GINI & $(\mathrm{c}, 0,0)$ & -1.4590 & -3.7529 & Unstable \\
$\triangle \mathrm{LN}$ GINI & $(\mathrm{c}, 0,0)$ & $-4.8154^{* * *}$ & -3.7695 & Stable \\
LN THEIL & $(\mathrm{c}, \mathrm{t}, 2)$ & -1.1395 & -3.7529 & Unstable \\
$\triangle \mathrm{LNTHEIL}$ & $(\mathrm{c}, \mathrm{t}, 0)$ & $-4.9007^{* * *}$ & -3.7695 & Stable \\
\hline
\end{tabular}

Note: In above table, $\quad$ serdepredisfeterfostc represents constant term; t represents trend term; p represents lag order; * represents significance of Mackinnon critical value below $10 \%$; ** represents significance of Mackinnon critical value below $5 \%$; *** represents significance of Mackinnon critical value below $1 \%$.

The equation obtained by VAR vector auto-regression model estimation can only reflect the local dynamic relationship between the industry income gap and the financial development rather than the global dynamic relationship between the industry income gap and the financial development. Therefore, the equation obtained thereby cannot be separately adopted for the analysis, and such methods or tools as impulse response function [3], variance decomposition [4], Granger causality test [5] should be adopted in order to comprehensively reflect the degree of the influence of the industry income gap on the financial development. Accordingly, such analysis tools as impulse response function, variance decomposition and Granger causality test are adopted in this paper to gradually analyze the influence of the industry income gap on the financial development.
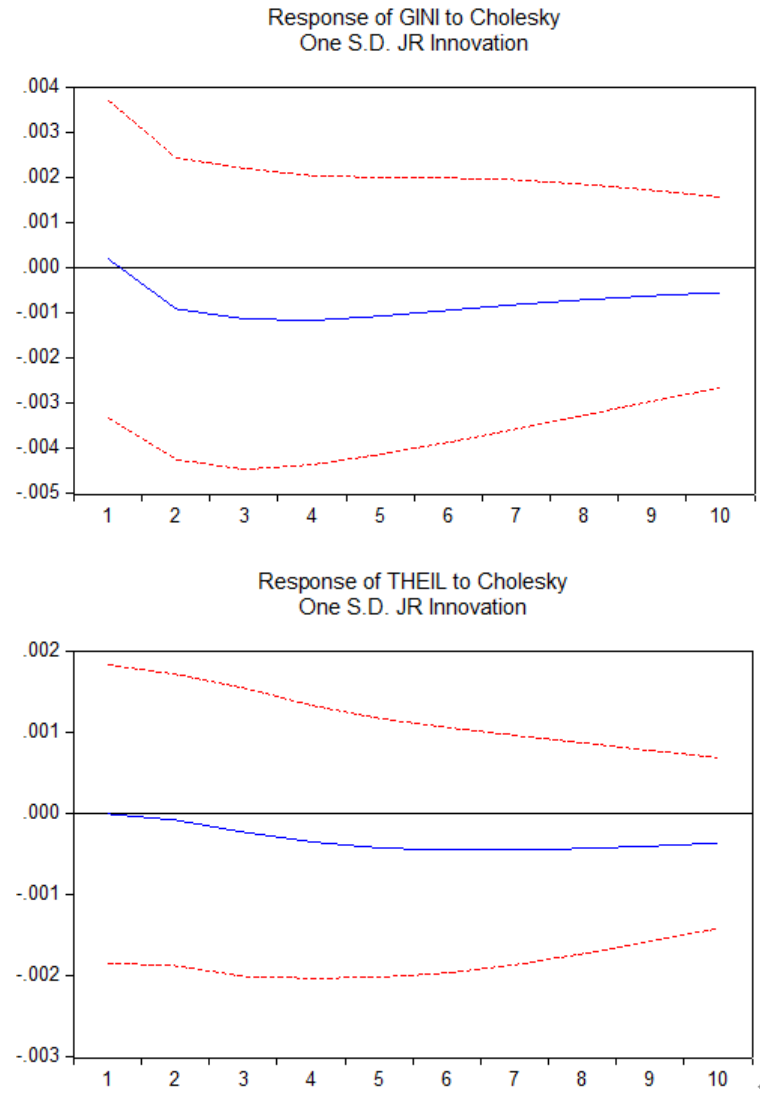

Fig. 1. Influence of Industry Income Gap on Financial Development

As shown in Fig.1, in the diagram for impulse response function of the industry income gap to the financial development, the full line represents the impact of the industry income gap on the financial development, and the curve formed by the degree of the response of the financial development to the industry income gap is namely the impulse response curve, and the dotted line represents the impulse response curve with double standard error. The horizontal axis represents the trace periods and the vertical axis represents the degree of the response of the financial development to the impact of the industry income gap. The industry Gini coefficient tends to positively influence and then negatively influence the financial development. In the 1st period, the industry Gini coefficient has positive effect on the financial development; since the 2nd period, the industry Gini coefficient has negative effect on the financial development and has the maximum negative effect in the 4th period; after the 5th period, the industry Gini coefficient has negative effect on the financial development and such negative effect tends to be stably reduced. The industry Theil index has negative effect on the financial development and the negative effect reaches the maximum value at the stage from the 1st period to the 5 th period; after the 6th period, the negative effect of the industry Theil index on the financial development tends to be stably reduced.

As shown in TABLE III, according to the variance decomposition results of the industry income gap and the financial development, the contribution of the industry income gap in China to the financial development tends to be gradually 
reduced, thus indicating that the effect of the industry income gap tends to be gradually weakened in the change of the financial development.

TABLE III. VARIANCE DECOMPOSITION OF INDUSTRY INCOME GAP AND FINANCIAL DEVELOPMENT

\begin{tabular}{ccccc}
\hline Period & JR & GINI & CYJG & THEIL \\
\hline 1 & 0.0570 & 99.9429 & 0.0002 & 99.9997 \\
2 & 0.8050 & 99.1949 & 0.0222 & 99.9777 \\
3 & 1.4791 & 98.5208 & 0.1465 & 99.8535 \\
4 & 1.9843 & 98.0156 & 0.3689 & 99.6310 \\
5 & 2.2909 & 97.7090 & 0.6382 & 99.3617 \\
6 & 2.4630 & 97.5369 & 0.9052 & 99.0948 \\
7 & 2.5541 & 97.4458 & 1.1414 & 98.8585 \\
8 & 2.6002 & 97.3997 & 1.3367 & 98.6632 \\
9 & 2.6229 & 97.3770 & 1.4921 & 98.5078 \\
10 & 2.6339 & 97.3661 & 1.6131 & 98.3868 \\
\hline
\end{tabular}

Finally, after impulse response function operation and variance decomposition, in order to determine whether the causal relationship exists between the industry income gap and the financial development, it is necessary to further carry out Granger causality test. As shown in TABLE IV, after the long-term co-integration relationship is determined to exist between the industry income gap and the financial development, according to the results of the Granger causality test for the industry income gap and the financial development, the industry Gini coefficient is not the cause for the financial development, but the financial development is the cause for the industry Gini coefficient; the industry Theil index is not the cause for the financial development, and the financial development is also not the cause for the industry Theil index, thus indicating that the financial development is the cause for the expansion of the industry income gap.

TABLE IV. GRANGER CAUSALITY TESTS OF INDUSTRY INCOME GAP AND FINANCIAL DEVELOPMENT

\begin{tabular}{lcc}
\hline Null Hypothesis & F-Statistic & Prob. \\
\hline GINI does not Granger Cause JR & 0.3917 & 0.8104 \\
JR does not Granger Cause GINI & 3.5948 & 0.0414 \\
THEIL does not Granger Cause JR & 0.3802 & 0.8182 \\
JR does not Granger Cause THEIL & 2.3717 & 0.1160 \\
\hline
\end{tabular}

\section{CONCLUSION}

After the logical analysis the paper adopts the macroscopic statistical data for the empirical research on the influence of the industry income gap on the financial development. Firstly, the unit root test is carried out the financial development index and the industry income gap index to determine whether the dependent variable and the independent variable selected thereby can be adopted for VAR model estimation; secondly, VAR model estimation is carried to judge whether a long-term co-integration relationship exists between the industry income gap and the financial development; finally, Granger causality test is carried out to determine whether a causal relationship exists between the industry income gap and the financial development.

The research shows that the effect of the industry income gap tends to be gradually weakened in the change of the financial development. The improvement of the financial development level in China is the cause for the expansion of industry income gap, and the non-balanced financial development in various industries significantly expands the industry income gap. Therefore, the government should not only concern the urban-rural financial development gap, but also attach importance to the inter-industry financial gap.

\section{REFERENCES}

[1] Maddala G S, Wu S. A comparative study of unit root tests with panel data and a new simple test[J]. Oxford Bulletin of Economics and statistics, 1999, 61(S1): 631-652.

[2] Lütkepohl H. Vector autoregressive models[M]. Springer Berlin Heidelberg, 2011.

[3] Lütkepohl H. Impulse response function[M]//Macroeconometrics and Time Series Analysis. Palgrave Macmillan UK, 2010: 145-150.

[4] Campbell J Y. A variance decomposition for stock returns[R]. National Bureau of Economic Research, 1990.

[5] Granger C W J. Some recent development in a concept of causality[J]. Journal of econometrics, 1988, 39(1): 199-211. 